\title{
Sociální práce v dialogu s teologií - Myšlenky k významu spravedlnosti a milosrdenství pro sociální práci Stephanie Bohlen
}

\begin{abstract}
Abstrakt
Je vedena diskuse o oprávněnosti kritiky milosrdenství jako základu motivace sociálního jednání, která byla vznesena v kontextu profesionalizačního procesu sociální práce. Po vyjasnění relevantních pojmů je diskutován vztah mezi milosrdenstvím a spravedlností. Cílem diskuse je zamezit neoliberálnímu zužování pojmu spravedlnosti, které by mohlo mít za následek omezení solidarity. Je poukázáno na to, že sociální práce může dostát svému úkolu jen při profesionálním úsilí o sociální spravedlnost ve spojení s připomínáním možnosti milosrdného jednání, u níž je objasněno její působení na utváření solidarity.
\end{abstract}

Klíčová slova: sociální práce, profese lidských práv, paradigma služeb, skutky milosrdenství, spravedlnost, teologie, prorocká tradice

\section{Sociální práce bez „milosrdného samaritánství“?}

„International Federation of Social Workers (IFSW - Mezinárodní federace sociálních pracovníků)“ uvádí jako základ principů sociální práce „respektování vlastní hodnoty a důstojnosti všech

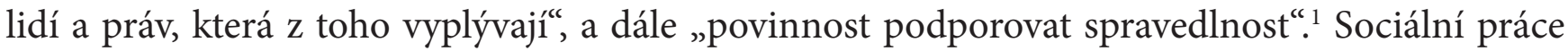
je tedy chápána $\mathrm{z}$ hlediska její funkce. Jejím úkolem je podporovat sociální spravedlnost při respektování lidské důstojnosti. Z tohoto hlediska je možné ji chápat jednak jako „profesi lidských práv“,2 jednak jako „profesi spravedlnosti“3 Interpretace sociální práce jako profese lidských práv je v Německu spojena se jménem Silvia Staub-Bernasconi. ${ }^{4}$ Ve svém zásadním pojednání z roku

1 ○ IFSW / IASSW, Ethik in der Sozialen Arbeit - Darstellung der Prinzipien, 2004 (on-line), dostupné na: http://www.avenirsocial.ch/ cm_data/EthikprinzSozArbeitIFSW.pdf, citováno dne 24. 01.2018.

2 Srov. Silvia STAUB-BERNASCONI, Das fachliche Selbstverständnis Sozialer Arbeit - Wege aus der Bescheidenheit. Soziale Arbeit als „Human Rights Profession“, in: Soziale Arbeit im Wandel ihres Selbstverständnisses: Beruf und Identität, ed. Rolf Rainer WENDT, Freiburg im Breisgau: Lambertus, 1995, s. 57-104. Srov. také Silvia STAUB-BERNASCONI, Soziale Arbeit: Dienstleistung oder Menschenrechtsprofession? Zum Selbstverständnis Sozialer Arbeit in Deutschland mit einem Seitenblick auf die internationale Diskussionslandschaft, in: Ethik Sozialer Arbeit. Ein Handbuch, ed. Andreas LOB-HÜDEPHOL - Walter LESCH, Paderborn, München, Wien, Zürich: UTB, 2007, s. 20-53.

3 Mark SCHRÖDTER, Soziale Arbeit als Gerechtigkeitsprofession. Zur Gewährleistung von Verwirklichungschancen, Neue Praxis 1/2007, s. 3-28; Christiane FALLER - Nina THIEME, Soziale Arbeit als Gerechtigkeitsprofession. Eine Konturierung aus disziplinärer Perspektive, Soziale Arbeit 2/2013, s. 53-59.

4 Srov. pozn. 2. 
1995 spojuje svůj požadavek, aby byla sociální práce chápána jako profese lidských práv, s kritikou náboženských kořenů sociální práce. Po dlouhou dobu byla sociální práce koncipována nábožensky jako forma „milosrdného samaritánstvi“ ${ }^{5} \mathrm{~V}$ důsledku toho se požadovalo sociální jednání, kterým se pomoc chápala jako péče. Avšak péče je formou poručnictví, heteronomie. Kvůli autonomii potřebných lidí je třeba takovéto koncepty sociálního jednání odmítnout.

Teze, že sociální práce si vystačí bez rekursu na milosrdenství, je dodnes zastávána v různých variantách. ${ }^{6} \mathrm{~S}$ ní je nezřídka spojována také teze, že sociální práce se musí rozloučit s dialogem s teologií jako jedné ze svých vztažných věd, protože jinak by nebylo možné ze sociální práce vyčlenit pojem milosrdenství či s ním korelující základní postoj péče. Profesionální sociální práci se přitom přisuzuje, že je určována perspektivou spravedlnosti, a ne motivací milosrdenství.

Já osobně se nedomnívám že v moderní sociální práci není pro milosrdenství místo. ${ }^{7}$ Naopak: Úkolem sociální práce $\mathrm{v}$ dnešní společnosti je angažovanost pro sociální spravedlnost, $\mathrm{v}$ níž lze rozpoznat jednotu spravedlnosti a možnosti milosrdenství v teorii a praxi. Proto chci své úvahy ohledně etiky sociální práce zaměřit na význam milosrdenství pro sociální jednání. $\mathrm{K}$ tomu je potřeba nejprve vysvětlit, jak je nutno chápat pojem milosrdenství. Zaměřím se tedy na toto objasnění pojmu, a sice tak, že za výchozí bod svých úvah přijmu rizika, která skutečně mohou vznikat tam, kde sociální práce rozvíjí své sebepojetí v dialogu s teologií, aniž by jej zasadila do souvislostí s teologicky reflektovaným pojmem milosrdenství. Po vyjasnění termínu následně pojednám o šancích, které by mohly pro sociální práci vyplynout z akceptace milosrdenství jako jednoho z motivů sociálního jednání.

\section{Skutky milosrdenství}

Podívejme se na náboženské př́iběhy, na kterých se zakládá požadavek milosrdenství! Vypravují o soudu na konci časů. Postavení soudce zaujímá Syn člověka. Vyslovuje právo ve jménu svého Otce. Části lidstva přisuzuje Syn právo vejít do království Otce. Svůj rozsudek zdůvodňuje takto:

Měl jsem hlad, a dali jste mi najíst, žíznil jsem, a dali jste mi pít, neměl jsem střechu nad hlavou, a vy jste mne přijali, neměl jsem co na sebe, a vy jste mne oblékli, v nemoci jste o mne pečovali, a když jsem byl ve vězení, přišli jste za mnou. (Mt 25,35-36)

Tento text uvádí jednání, která spolu s pohřbíváním mrtvých tvoří „sedm skutků milosrdenstvi“. Stojí v centru středověké etiky. Jsou lidem středověku názorně postaveny před oči, aby bylo zjevné: Máš milovat svého bližního. A: Bližní je každý, kdo trpí nouzí, a tudíž potřebuje tvoji pomoc. Text dosahuje svého cíle v identifikaci soudce, který soudí v Božím jménu, s těmi, kdo potřebují pomoc. Ti, kterým je přislíbeno království, se ptají, kdy zažili soudce hladového, žíznivého, bez domova nebo nemocného. A soudce odpovídá, že co člověk učinil pro druhého, učinil současně i pro něj (Mt 25,40). Je zde znázorněna jednota lásky k Bohu a lásky k bližnímu, o níž pojednává také př́běh o milosrdném Samaritánovi (L 10,25-37).

\section{Od kritiky „milosrdného samaritánstvi““ k etice sociální práce}

Kromě obrazů a soch jsou to životopisy svatých, kde lze nahlédnout, co znamená milovat bližního. V listopadu je svátek svatého Martina. O něm se vypravuje, že se rozdělil s člověkem, který neměl

5 STAUB-BERNASCONI, Das fachliche Selbstverständnis Sozialer Arbeit - Wege aus der Bescheidenheit..., s. 60.

6 Hans GÄNGLER - Ulrich KLEINERT, Barmherzigkeit, in: Theologie und Soziale Wirklichkeit. Grundbegriffe, ed. Volker HERRMANN - Ralf HOBURG - Ralf EVERS - Renate ZITT, Stuttgart: Kohlhammer, 2011, s. 34-44, zvl. s. 38.

7 Ale srov. Niklas LUHMANN, Formen des Helfens im Wandel gesellschaftlicher Bedingungen, in: Gesellschaftliche Perspektiven der Sozialarbeit, Bd. 1, ed. Hans-Uwe OTTO - Siegfried SCHNEIDER, Neuwied, Berlin: Luchterhand, 1973, s. 21-43. 
oblečení, o to, co sám měl: o svůj plášt. Rozdělení pláště se událo spontánně, z pohnutí nad bídou chudého člověka, aniž by o tom Martin musel přemýšlet. Rozdíl mezi spontánním jednáním světce a reflektovaným jednáním, které vyžaduje moderní sociální práce, lze sotva přehlédnout. Na základě vlastní spontánnosti se jednání světce omezilo také jen na setkání s chudým mužem. Neměl na zřeteli společnost, ale jen toho chudého muže. Jestli bylo žádoucí nejen pomoci jednomu chudému, ale zaměřit se na celý společenský systém, není vůbec hodnoceno. Středověká láska $\mathrm{k}$ bližnímu není kritická vưči systému. Moderní sociální práce by však měla být.

Na obrazech znázorňujících dělení pláště se zobrazuje náklonnost světce zpravidla tak, že se sklání $\mathrm{k}$ chudákovi. Martin se shora obrací k tomu, kdo je dole, tedy bezmocný. Ten prožívá svoji vlastní bezmoc právě také tím, že je mu pomáháno. Kde sociální jednání podporuje prožitek bezmoci, tam odporuje cíli zplnomocnění $\mathrm{k}$ samostatnému životu i těch, kdo potřebují pomoc. Pozdní středověk je pak doba, ve které se $\mathrm{z}$ asymetrického vztahu pomáhajícího $\mathrm{k}$ potřebnému člověku stává instrumentalizace toho, kdo potřebuje pomoc. V pozdním středověku se stává strach ze soudu určitým životním pocitem. Někteří mohou vejít do království. Ale co bude se mnou? Měl bych dělat více proto, abych byl spasen? Zasloužil jsem si spásu? Pod vlivem takovéhoto strachu se mění jednání z milosrdenství na jednání ze strachu o vlastní spásu. V potřebném člověku je pak viděn pouze ten, na kterém si člověk může získat zásluhy na cestě na věčnost. Proti takovéto instrumentalizaci je třeba protestovat, at už kvưli člověku, či také z teologických důvodů. ${ }^{8}$

V kritice „milosrdného samaritánstvi“ lze sledovat vůdčí linie etiky sociální práce, která chce mít statut moderní profese.

\section{Profesionální sociální práce}

- není spontánní konání, ale reflektované jednání;

- není zaměřena jen na potřebné lidi, ale také na struktury společnosti;

- neinstrumentalizuje potřebné lidi, ale respektuje je v jejich vlastní důstojnosti;

- nestaví lidi v procesu pomoci pod poručnictví, ale je zaměřena na jejich zmocnění $\mathrm{k}$ samostatnému životu.

Pokud by se pod „milosrdenstvím“ chápalo jen nereflektované sklánění se k těm, kteří potřebují pomoc, a pod „milosrdným jednáním“ jen péče, která má za následek to, že potřební lidé zažijí svoji bezmoc namísto uschopnění $\mathrm{k}$ samostatnému životu, nemohla by sociální práce skutečně jinak, než vyžadovat odklon od „milosrdného samaritánství". A teologie by $\mathrm{k}$ tomu sotva mohla odmítnout dát svůj souhlas. Zůstává ovšem otázka, zda skutečně není možno a nutno „milosrdenství chápat i jinak.

V debatě o sebepojetí sociální práce se snoubí kritika pojmu milosrdenství s výzvou ke změně orientace. Místo kladení důrazu na milosrdenství by se sociální práce snad měla orientovat na termín spravedlnost. Místo sklánění se k druhým by se měla orientovat na uznávání důstojnosti člověka. Avšak pod důstojností člověka lze chápat všelicos. Otázka, zda důstojnost člověka je za-

8 Klaus BAUMANN poukázal na to, že církev riziko výkladu milosrdného jednání, v němž jsou potřební lidé instrumentalizováni, sama poznala, a proto také uvedla na II. vatikánském koncilu jasné požadavky na „skutky lásky“ (Apostolicam Actuositatem, 8.5). Srov. Klaus BAUMANN, Die katholische lehramtliche Position zur Sorge um die Armen und Bedrängten aller Art, in: Helfendes Handeln im Spannungsfeld theologischer Begründungsansätze, ed. Christoph SIGRIST - Heinz RÜEGGER, Zürich: Theologischer Verlag, 2014, s. 111-122, zvl. s. 118n. a Klaus BAUMANN, Wieso „Barmherzigkeit“? In: Werke der Barmherzigkeit. Mittel zur Gewissensberuhigung oder Motor zur Strukturveränderung?, ed. Edeltraud KOLLER - Michael ROSENBERGER - Anita SCHWANDTNER, Linz, 2013 (LiWiRei, 5), s. 72-83, (on-line) dostupné na: http://www.wiege-linz.at/band5, citováno dne 24. 01. 2018. 
ložena $\mathrm{v}$ jeho bytí, zda je základním principem jeho uznání nebo zda je to jen prázdný pojem, je zodpovídána různě. ${ }^{9} \mathrm{~A}$ ani pojem spravedlnost rozhodně není jednoznačným pojmem. ${ }^{10}$ Pluralita významů, na kterou poukázal Aristoteles, umožňuje také rozdílné koncepty sociální spravedlnosti, z nichž lze uvést např. „spravedlnost potřeb“, „spravedlnost uschopnění”, „spravedlnost účasti“ a „spravedlnost smluvní. $Z$ tohoto důvodu by mohl být dialog s teologií relevantní pro zodpovězení otázky, co se má v sociální práci chápat pod důstojností člověka na jedné straně a pod sociální spravedlností na straně druhé. Vycházím z toho, že teologie je postavena před úkol připomínat $\mathrm{v}$ dialogu, že v kontextu sociální práce nesmí být redukován ani respekt $\mathrm{k}$ důstojnosti člověka na respekt $\mathrm{k}$ jeho sebeurčení, ani povinnost angažovanosti pro sociální spravedlnost na požadavek smluvní spravedlnosti. To, že takováto redukce je nejen možná, ale že představuje vlivem aktuálních společenských procesů zvýšené riziko pro sociální práci, se stále více ukazuje v debatě $\mathrm{v}$ německojazyčném prostředí.

\section{Sociální práce jako služba a neoliberální výklad pojmů „lidská důstojnost“ a "spravedlinost"}

Sociální pracovníci a pracovnice jsou zaměstnáni jako profesionální poskytovatelé služeb. V náplni práce mají nejen pomáhání lidem, ale také získávání prostř̌edků k financování zařízení, ve kterém pracují. Kde jde o financování zařízení, stávají se sociální služby nabídkami na trhu, které jsou poptávány lidmi, kteří mohou uplatnit své nároky. Právní stát, považující sám sebe za sociální stát, je povinen financovat nebo refinancovat sociální služby, aby i ti, kteří nedisponují požadovanými ekonomickými zdroji, mohli realizovat své nároky. Státním financováním sociálních služeb mění stát potřebné lidi na „zákazníky“, kteří mohou poptávat nabídky na trhu sociálních služeb. Spolu s rozlišováním mezi nabídkami, které jsou dobře refinancované, a sociálními službami, jejichž refinancování neopravňuje použití prostředků, ovšem následně vznikají také „výhodní zákazníci" a takoví, kteří pro provozovatele zařízení nejsou atraktivní. ${ }^{11}$

Kdo očekává od církevních společností fungujících coby provozovatelé sociálních zařízení, že se budou ujímat i těch, kteří nepatří k „výhodným zákazníkům“, a budou jim nabízet svou pomoc tam, kde sociální služby nejsou dobře refinancovány, vyžaduje implicitně, že takové společnosti by měly požadavkům trhu odporovat svou vlastní logikou, a sice logikou milosrdenství. Avšak mohou církevní společnosti odporovat trhu s odvoláním na požadavek milosrdenství? Nedošlo by vlastně k odmítání naší společnosti? Anebo se mají i církve a jejich charity, které jsou přece součástí naší ekonomizované společnosti, podrobovat trhu? Nemají jinou možnost, než umistovat své nabídky na trhu sociálních služeb a tam vyhlížet „,ýhodné zákazníky“?

Koncepce sociální práce podle paradigmatu služeb je podporována neoliberalistickými tendencemi v naší společnosti. ${ }^{12} \mathrm{~V}$ centru neoliberalismu stojí právo na individuální svobodu. Tu je třeba bezpodmínečně respektovat, je přece základem důstojného života člověka. Lidé jsou nahlíženi jako svobodní jedinci, kteří se socializují. Společenská smlouva a hranice, které si stanovují, slouží jako rámec umožňující vytvářet efektivně statky, které slouží dobrému životu. Statky se vyměňují na trzích. Člověk neoliberalismu je tedy jedinec s právem účasti na trhu a s povinností dodržovat

9 Srov. Franz Josef WETZ, Illusion Menschenwürde, in: Der Wert der Menschenwürde, ed. Christian Thies, Paderborn: Schöningh, 2009, s. $45-62$.

10 Srov. Werner VEITH, Gerechtigkeit, in: Christliche Sozialethik. Ein Lehrbuch, Bd. 1, ed. Marianne HEIMBACH-STEINS, Regensburg: Pustet, 2004, s. 315-326.

11 Roland LUTZ, Perspektiven der Sozialen Arbeit, Aus Politik und Zeitgeschichte 12-13/2008, s. 3-10.

12 Srov. STAUB-BERNASCONI, Soziale Arbeit: Dienstleistung oder Menschenrechtsprofession ..., s. 28. 
uzavřené závazky, tržní dohody a smlouvy. V tomto kontextu se požaduje respekt vưči individuální svobodě. Jeden jedinec respektuje druhého jedince, přičemž se drží smluv, které byly svobodně uzavřeny. Stát je povinen pokud možno nezasahovat regulačně do trhů, v nichž jednotlivci žijí svou svobodu. Stát dbá na důstojnost jednotlivců a zasazuje se za spravedlnost, přičemž právně zajištuje férovost smluvních poměrů.

\section{Na cestě $k$ teologicky inspirovanému novému výkladu pojmů „lidská di̊stojnost" a "spravedlnost"}

Jedním z úkolů teologie by mohlo být zaujmout stanovisko k neoliberalismu a jeho pojetí člověka. Abychom mohli položit základ takovému stanovisku, použiji v následujícím textu podnětu Jürgena Habermase. Habermas zastával tezi, že v našich dějinách došlo ke spásným překladům náboženských termínů do jazyka moderny. Odkazuje na termín „obraz Boží: „Přeložení pojmu člověka jako Božího obrazu do pojmu shodné a bezpodmínečně nutně respektované důstojnosti všech lidí je jedním z takovýchto spásných překladů. "13

Jestliže existuje možnost překladu náboženských pojmů do jazyka moderny, je možné se dát i opačnou cestou: uskutečnit výklad moderních pojmů v odkazu na náboženské tradice. Zvu tedy $\mathrm{k}$ takové cestě s úmyslem pomocí nového výkladu zviditelnit významové obsahy pojmů, které by $\mathrm{v}$ rámci moderny a jejích neoliberalistických tendencí mohly upadnout v zapomnění. To se týká jak pojmu důstojnosti, tak také pojmu spravedlnosti.

Pro neoliberalismus je důstojnost základem práva na sebeurčení či autonomii, které stojí v centru všech lidských práv. Kdo postaví autonomii člověka do středu pozornosti, ten interpretuje člověka jako svobodnou bytost, která je zodpovědným subjektem svých vlastních jednání. Také náboženská tradice, která vidí v člověku Boží obraz, spojuje postavení člověka, které mu na základě Božího obrazu v něm náleží, s jeho zodpovědností. V modlitbě nalezneme rozjímání nad postavením člověka. Bůh sám ho ustanovil vládcem a položil mu vše k nohám (̌̌ 8,7, srov. Gn 1,28). Takovouto modlitbu je nutno zasadit do kontextu doby jejího vzniku a z této pozice ji chápat. Od toho, kdo vládne, se také očekávalo, že si je vědom své zodpovědnosti za to, čemu vládne. Vládnutí tedy $\mathrm{v}$ náboženské tradici, mimo jiné i v příbězích o stvoření, není spojováno pouze s mocí, ale velmi úzce rovněž se zodpovědností. ${ }^{14}$ Proto je také oprávněné chápat slova o důstojnosti člověka jako překlad myšlenky, že člověk je Božím obrazem.

Podíváme-li se nyní na to, co biblické příběhy sdělují v souvislosti s člověkem, ukáže se rozdílnost s neoliberálním chápáním člověka velmi zřetelně. V náboženské tradici jsou lidé interpretováni nejen jako svobodné bytosti, ale také jako zranitelné bytosti se svými potřebami. Vypravuje se o tom, že lidé trpí bídou, že potřebují potravu, že touží po bezpečí, po vlasti. Z tohoto pohledu je nemyslitelné, aby se potřeby člověka redukovaly pouze na potřebu autonomie. Lidé nechtějí jen žít v sebeurčení, chtějí také moci uspokojovat své základní potřeby. Proto nelze být vůči člověku spravedlivý jen respektováním jeho sebeurčení. Lidé musí být vnímáni a respektováni i jako bytosti se základními potřebami. Náboženská tradice připomíná chápání člověka, které je pro sociální práci nepostradatelné. ${ }^{15}$

V obraze soudu na konci časů, který nám předala náboženská tradice, se nemluví o milosrdenství.

13 Jürgen HABERMAS, Vorpolitische moralische Grundlagen eines freiheitlichen Staates. Stellungnahme, Zur Debatte 1/2004, s. 2-4, (on-line), dostupné na: http://www.kath-akademie-bayern.de/tl_files/Kath_Akademie_Bayern/Veroeffentlichungen/zur_debatte/ pdf/2004/2004_01_habermas.pdf, citováno dne 24.01.2018.

14 Wilfried HÄRLE, Dogmatik. 2., přepracované vydání, Berlín, New York: de Gruyter, 2000, s. 438.

15 STAUB-BERNASCONI, Dienstleistung oder Menschenrechtsprofession?..., s. 28. 
Spíše se ti, jimž je přislíbeno království, nazývají „spravedlivými“ (Mt 25,46). Skutky, které vykonali, byly tedy paradigmaticky takové skutky, které byly vykonány nebo měly být vykonány kvůli spravedlnosti. Tento příběh umožňuje tezi, že vůči druhému lze být spravedlivý jen tehdy, jestliže se respektují jeho potřeby. Jde o to vidět nouzi druhého a jednat solidárně.

Židovský zákon zavazuje k tomu, aby člověk směřoval svůj pohled na lidi žijící na okraji společnosti a aby se zasazoval o spravedlnost (zedaka). Zákon přitom ohledně spravedlnosti neuznává dobrovolnost. ${ }^{16}$ Lidé jsou si spravedlnost navzájem dlužni. Dluží těm, kteří žijí na okraji společnosti, praktikovanou solidaritu. Tak má každý žid povinnost odvádět dávky, které se pak rozdělují chudým a potřebným, aby se omezila jejich chudoba. Kromě toho židovství zná možnost dobrovolných dávek (gemilut chassidim). Jednání popsané v př́iběhu o posledním soudu jsou právě takovéto skutky. Ti, kteří se nazývají „spravedlivými“, svým jednáním předčili závazky plynoucí ze zákona. Podle toho si lidé nejsou sobě navzájem povinováni jen na základě zákonů, a měli by tedy kvůli spravedlnosti činit i více než jen to, co od nich zákon požaduje. Tam, kde člověk jedná milosrdně, čerpá také potenciály lásky, lidskosti, které je schopen. Přitom platí: Jak v úkolu, ke kterému je žid zavázán ze zákona, tak také v dobrovolném daru se realizuje láska k bližním, ve které zakouší Boží láska svoji konkrétnost. Přitom se neuvažuje o možnosti nahradit povinnost jednání kvưli spravedlnosti dobrovolným skutkem lásky.

Ve vyprávění o soudu na konci časů se pojem milosrdenství nevyskytuje. Avšak v dalším textu byla povinnost takovýchto dobrovolně vykonávaných skutků přesahujících požadavky zákona vázána na milosrdenství. Rozlišování takových „skutků lásky“, které člověk druhým dluží, od těch, které přesahují povinnost jednotlivce, našlo cestu do křest’anské teologie. Tomáš Akvinský to uvedl v následující formulaci:

\section{Milosrdenství neruší spravedlnost, spíše je naplněním spravedlnosti. ${ }^{17}$}

Rozlišování milosrdenství a spravedlnosti tedy připomíná, že člověk má schopnost koncipovat spravedlnost nejen podle logiky právních závazků, ale i podle člověka, který ze své zranitelnosti zavazuje k pomoci, a sice $\mathrm{k}$ takové, která se konkretizuje v umožnění lidsky důstojné existence na základě citlivého vnímání existenciální potřeb.

Jak může sociální práce profitovat z dialogu s teologií? Svými texty o možnosti milosrdenství teologie připomíná, že lidé mají potenciál citlivě vnímat potřeby druhých. Vyzývá $\mathrm{k}$ tomu, aby vnímaným potřebám nepřiznávali platnost pouze v mezích, které určuje zákon tím, že uvádí potřeby do korelace s nároky. Pokud chceme být vůči nějakému člověku spravedliví, pak nesmíme přehlížet, že toho potřebuje více (a jinak) než jen to, co si může nárokovat s odkazem na zákon, a tedy i více pomoci než jen tu, která je dobře refinancovaná. Můžeme jen doufat, že je tomu věnována pozornost a že vědomí spravedlivých a právně nezajištěných nároků člověka způsobených jeho zranitelností je chápáno jako výzva k politické angažovanosti pro větší spravedlnost. Zda jsou takové naděje oprávněné, je možné definovat v dialozích o chápání důstojnosti, spravedlnosti a milosrdenství, které musí sociální práce vést, pokud se chce postavit svým vlastním neoliberálním zúžením. Pokud mohou náboženské př́běhy, jejichž výklad je úkolem teologie, učinit citlivějším $\mathrm{k}$ tomu, aby se důstojnost člověka neredukovala jen na základ jeho práva na sebeurčení, ale aby se konkretizovala z hlediska základních potřeb člověka, mělo by být pro sociální práci užitečné neodmítat dialog s teologií.

16 Reuven Bar EPHRAIM, Mitmenschliche Solidarität im Judentum, in: Helfendes Handeln im Spannungsfeld theologischer Begründungsansätze, ed. Christoph SIGRIST - Heinz RÜEGGER, Zürich: Theologischer Verlag, 2014, s. 43-49.

17 Thomas von Aquin, Summa theologica I 21, 3 ad 2. 


\section{Připomínka Božího milosrdenství: základ motivace $k$ angažovanosti pro lidskou di̊stojnost a spravedlnosti?}

Habermas poukázal na to, že tržní logika by mohla zničit každé solidární vztahy, které vyžadují sociálně spravedlivé utváření společnosti. Je třeba uvážit, že náboženské příběhy by mohly být pramenem, se kterým by stát měl zacházet $s$ respektem..$^{18}$ Náboženské př́iběhy jsou zdrojem, ze kterého společnost a s ní i sociální práce mohou čerpat tam, kde jde o posílení solidarity. Čerpat ze zdroje ale neznamená pouze apelovat na spravedlivé a milosrdné jednání. Nebợ dřive, než je možné vyslechnout výzvu, už jednal Bůh milosrdně. Víra v milosrdného Otce, jak má ozřejmit poslední myšlenkový krok, je významný zdroj posílení solidárních vztahů.

Židé si v modlitbě připomínají: „Pán je milostivý a spravedlivý, náš Bůh je milosrdný“ (Ž 116,5, srov. Ž 86, 15; Ž 145,8. Srov. také Ex 34, 6, Num 14, 18). V zážitcích milosti, spravedlnosti a milosrdenství zakoušejí to, jak Bůh jedná, a tím i kdo Bůh je. V jeho milosrdenství se zjevuje jeho božství. ${ }^{19}$ Dějiny Boží $s$ jeho národem Izraelem je proto možné vyprávět jako dějiny milosrdenství. Bůh učinil Izraelity svým národem. Spojil se s tímto lidem, stojí za smlouvou, kterou uzavřel. Avšak lid tuto smlouvu porušil a nedbá už na Boží přikázání. A jsou to proroci, kdo tematizuje následky porušení smlouvy. Jedním z nich je prorok Ámos. Protože lid už nedodržuje přikázání, vznikají sociální poměry, které prorok nazývá pravým jménem: utiskování slabých, vykořistování chudých, zbavení práv bezmocných. Ámos připomíná, že vykořistování je umožňováno nespravedlivým rozdělením moci a bezmoci, a v Božím jménu požaduje spravedlnost pro chudé. Nenahrazuje zákon spravedlnosti požadavkem milosrdenství. Avšak pro naši otázku je relevantní, že požadavek spravedlnosti mezi lidmi zasazuje do kontextu připomínání Božího milosrdenství. Lid porušil smlouvu. Kdyby Bůh oplácel stejné stejným, musel by se od svého lidu, který se provinil porušením smlouvy, odvrátit. Avšak Bůh je „svatý“. „Rozpomíná se na své slitování a přiklání se ke svému lidu, aniž by bral v potaz, zda si lid jeho náklonnost také zasloužil.

Bůh, jak je připomínáno, sice jednou nezakročil, když byl lid vytržen ze země, ve které se usadil. Avšak nyní se milosrdný Bůh znovu přiklání ke svému lidu. Prorok prohlašuje v Božím jménu:

Úděl Izraele, svého lidu, změním, oni znovu vybudují zpustošená města a osídlí je, vysadí vinice a budou z nich pít víno, založí zahrady a budou z nich jíst ovoce. Zasadím je do jejich půdy a již nikdy nebudou vykořeněni ze své země, kterou jsem jim dal, praví Hospodin, tvůj Bůh. (Am 9,14,15).

Bůh sám dá lidu Izraele vlast tam, kde hory oplývají vínem, země je plodná a v zahradách roste vše, co člověk potřebuje. Avšak tím to přece není učiněno. Prorok Ámos vychází z toho, že to, co teologie nazývá „spásou“ a sociální práce „dobrým životem“, může být myšleno pouze jako život, ve kterém se jedinci jednak dostává všeho potřebného, a jednak jsou také zachovávána jeho práva. V Božím městě se valí právo jako vody, spravedlnost jak proudící potok (Am 5,24). Vratme se ale ještě jednou ke kritice „milosrdného samaritánstvi“'. S ohledem na prorockou tradici je kritika oprávněná jen částečně. Není pravdou, že tam, kde se základem sociálního jednání stává milosrdenství, je vyloučena otázka spravedlnosti. Prorok připomíná mocným, že vykořistování, utlačování a zbavování práv je bezpráví. Nevyzývá k tomu, aby se k slabým, utiskovaným a lidem

18 HABERMAS, Vorpolitische moralische Grundlagen des freiheitlichen Staates..., s. 3.

19 Walter KASPER, Barmherzigkeit. Grundbegriff des Evangeliums - Schlüssel christlichen Lebens, Freiburg, Basilej, Vídeň, 2012 , s. 58 a 94. 
zbavených práv skláněli. Ámosovým záměrem je, aby mocní uznali, že všichni lidé mají právo na to, co potřebují k životu. Kdo chce být vưči lidem spravedlivý, nesmí nikoho vykořistovat, ale musí se s ostatními dělit o to, co má. Povinnost dělit se ale není formulována ani jen jako etická výzva, ani není zdůvodněna pouze právně. Jako důvod motivace pro tento závazek je uvedeno Boží milosrdenství. To je mocnější než logika, v níž se jen stejné oplácí stejným, mocnější než logika smlouvy. Prorok spoléhá na to, že s připomenutím Božího milosrdenství je spojeno vědomí, že štěstí, které člověk sám smí prožívat, není jen důsledkem jeho vlastních zásluh, a obdobně že nouze druhého člověka není pouze jeho vlastní vina. Pro sociální práci, jejíž angažovanost pro spravedlnost musí směřovat také k podporování solidarity, by bylo dobré, aby věnovala pozornost zdroji, jenž připomíná, že otázka, zda si druhý člověk zaslouží, abych se s ním dělil, se tím stává otázkou, pro niž je Boží milosrdenství kamenem úhelným.

Překlad: Mgr. Marta Rynešová

\section{Kontakt}

Prof. Dr. theol. Stephanie Bohlen

Katholische Hochschule Freiburg

Karlstraße 63, 79104 Freiburg

stephanie.bohlen@kh-freiburg.de 